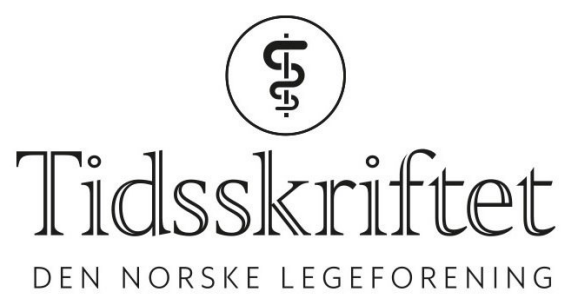

\title{
Målet må være forbedring, ikke frykt
}

KOMMENTAR

KARIANNE FLAATTEN

E-post: karianne@gmx.de

Karianne Flaatten er assisterende fylkeslege i Hordaland.

Ingen oppgitte interessekonflikter.

Leger gjør feil og vi må tørre å snakke om det, skriver Kathrine F. Vandraas i Tidsskriftet (1). Vandraas trekker frem vinkristin-saken på Haukeland som et eksempel der legen blir eksponert og pekt på i media, og viser til belastningen det er for helsepersonell å bli uthengt slik. Jeg deler Vandraas sitt ønske om mer åpenhet rundt at ting kan gå galt.

Jeg jobber nå som assisterende fylkeslege, men med flere år i arbeid på sykehus før dette, i et fag fullt av raske beslutninger og kort vei fra liv til død, har jeg langt ifra glemt mine egne feil. Blodprøven jeg overså, doseringen jeg regnet feil, feilvurderinger av hvilke pasienter jeg skulle prioritere. Det at man selv har navigert i slike farvann, og gått på skjær iblant, er en viktig erfaring for å kunne vurdere andre som har vært uheldige. Både fylkeslegene og Helsetilsynet har til sammen både mye og bred klinisk kompetanse hos sine medarbeidere. Denne kompetansen, som vi kan og må bruke på tvers, er en forutsetning for å best mulig kunne normere og vurdere medisinsk praksis.

Når Helsetilsynet har lagt føringer for vurderinger i klage- og tilsynssaker har de i de siste årene særskilt vektlagt at det skal vurderes om det er gjort feil på systemnivå. Dette er et viktig skifte fra tiden der man fremfor alt rettet fingeren mot helsepersonellet. Ledernes ansvar for å legge til rette for forsvarlig helsehjelp har blitt tydeliggjort i egen forskrift (2). I svært mange saker er systemsvikten det viktigste, som i seg selv kan føre til økt risiko for individuelle feiltrinn. Media har ofte et ubarmhjertig fokus og har for lengst skjønt at overskriften «legetabbe» selger så det holder. Fremstillingen blir lett ensidig og feil vinklet. Systemfeilene får ikke like mye oppmerksomhet, og mange helsearbeidere mener at individuelle pliktbrudd rammer mye hardere enn påpekningen av systemsvikt.

Fylkeslegen er avhengig av tillit både blant befolkningen og i helsevesenet og trenger et godt samarbeid med begge parter. Vi jobber også med å realitetsorientere både media og de av våre klagere som har urimelige krav til helsevesenet og helsearbeiderne. Dersom vi som tilsynsmyndighet vurderer helsepersonell eller tjenestene på feil grunnlag vil vi både legge tunge stein til byrden for enkeltpersonene som er involvert og i tillegg underminere vår egen troverdighet som tilsynsorgan. I vårt arbeid må vi gjøre vårt beste for å være forutsigbare, relevante og ikke urimelige. Tilsynsmyndighetens mål er å bidra til forbedring, ikke å skape frykt for å utføre legevirket med alt det innebærer. De beste beslutningene tas av leger som inkluderer en kalkulert risiko, ikke av de som kun streber mot feilfrihet. Samfunnet er avhengig av at leger og helsetjenesten tar risiko i behandling av alvorlig syke pasienter. Medisinsk undersøkelse og behandling er alltid forbundet med 
usikkerhet, og alle avgjørelser er tatt med ulik grad av informasjon og tidspress. Nettopp derfor kan helsetjenesten aldri bli feilfri.

\section{LITTERATUR:}

1. Vandraas KF. Leger gjør feil. Tidsskr Nor Legeforen 2018. doi:10.4045/tidsskr.18.0210.

[PubMed][CrossRef]

2. Helse- og omsorgsdepartementet. Forskrift om ledelse og kvalitetsforbedring i helse- og omsorgstjenesten. 28.10.2016. https://lovdata.no/dokument/LTI/forskrift/2016-10-28-1250 (30.4.2018).

Publisert: 12. juni 2018. Tidsskr Nor Legeforen. DOI: 10.4045/tidsskr.18.0428

(C) Tidsskrift for Den norske legeforening 2020. Lastet ned fra tidsskriftet.no 